\title{
NCOR1 Gene
}

National Cancer Institute

\section{Source}

National Cancer Institute. NCOR1 Gene. NCI Thesaurus. Code C28640.

This gene is involved in chromatin remodeling and repression of transcription. 